\title{
WOJENNA PROZA WIKTORA ASTAFIEWA A PROBLEM NIENAWIŚCI I PRZEBACZENIA
}

\author{
VIKTOR ASTAFIEV' S WAR PROSE \\ AND THE PROBLEM OF HATRED AND FORGIVENESS
}

\author{
WAWRZYNIEC POPIEL-MACHNICKI
}

\begin{abstract}
Viktor Astafyev was an outstanding Russian writer and a representative of "village prose". In his oeuvre, along with works on the question of "man and nature", we may find numerous important works concerning the subject of war. Astafyev fought in WWII, which left him with some unhealed wounds. In his novels about this 'Great Patriotic War', the dominating pacifist humanism triggered the first depiction of German soldiers through the prism of Christian mercy in Russian literature. The attempt to analyze the novel The Cursed and the Slain is very relevant in light of our present reality, full of news of new military conflicts, including that in eastern Ukraine.
\end{abstract}

Wawrzyniec Popiel-Machnicki, Uniwersytet im. Adama Mickiewicza w Poznaniu, Poznań - Polska, wawerpma@amu.edu.pl

II wojna światowa, jak mogłoby się wydawać, powinna stać się ostrzeżeniem dla przyszłych pokoleń, mówiącym o tym, do czego doprowadza rozwiązywanie wszelkiego rodzaju problemów społeczno-politycznych w oparciu o metody siłowe. Jednak jak pokazała historia, od 1945 roku nie było ani jednego dnia na naszym globie, żeby w różnych częściach świata nie dochodziło do militarnych konfliktów. Mieszkańcy Europy ŚrodkowoWschodniej spoglądali na nie jak na zjawiska nie do końca realne, egzotyczne, oddalone, które nie mogą dotknąć ich bezpośrednio. Paradoksalnie efekt powojennego podziału Europy na dwa przeciwne obozy polityczne, pomiędzy którymi trwała ciągła zimna wojna, zakonserwował sytuację polityczno-militarną tej części świata i nigdy nie przekształcił się w realną, gorącą wojnę. Dla kolejnych pokoleń Europy Środkowo-Wschodniej wojna wciąż kojarzyła się z II wojną światową albo z Wielką Wojną Ojczyźnianą, jak nazywają ją Rosjanie, o której przez całe lata opowiadała literatura piękna, filmy, literatura faktu.

Obywatele krajów demokracji ludowej nie dopuszczali do siebie myśli, żeby jakikolwiek konflikt zbrojny rozgorzał blisko ich domów, a zwłaszcza pomiędzy bratnimi narodami, za które uchodziły społeczeństwa tzw. bloku wschodniego. Pierwszym poważnym ostrzeżeniem podważającym te optymistyczne założenia była wojna, która na początku lat 90. minionego wieku 
doprowadziła do podziału dawnej Jugosławii. Prawdziwym jednak szokiem był wybuch krwawego starcia pomiędzy Rosją a Ukrainą, których narody od wieków uchodziły za bratnie, najsilniej powiązane historycznie i kulturowo. Trudno uwierzyć, że ten konflikt rozgorzał pomiędzy ludźmi, z których wielu ramię w ramię doszło w 1945 roku do Berlina, o czym przez całe dziesięciolecia nie dawała zapomnieć radziecka proza wojenna. Niestety to nie zwykli ludzie decydują o wojnach, lecz politycy i różnej maści decydenci, którzy sprawiają wrażenie, że literatura piękna jest im obca i zupełnie niepotrzebna. Jeśli jest tak $\mathrm{w}$ rzeczywistości, to jest to pesymistyczna diagnoza. Lektura wielu książek o II wojnie światowej, a zwłaszcza autobiograficznych wspomnień, obnażających okropności tamtych wydarzeń, pozwoliłyby, być może, na większą refleksję i ostrożność przy podejmowaniu decyzji, mających bezpośredni wpływ na losy tysięcy, a nawet milionów ludzkich istnień

Doskonałym przykładem takiej cennej lektury jest twórczość przedstawiciela tzw. rosyjskiej prozy wiejskiej, prozaika wywodzącego się z kręgu pisarzy syberyjskich, Wiktora Astafiewa (1924-2001). W swojej twórczości, obok utworów poświęconych wsi rosyjskiej i nierozerwalnym więzom łączącym człowieka z przyrodą, autor Царь рыбы (1976) (Królowa ryb - 1980) zawsze pisał o wojnie. O rosyjskiej prozie wojennej, która stanowiła ważny element realizmu socjalistycznego, prozaik niejednokrotnie mówił, że reprezentują ją przede wszystkim byli żołnierze, prawdziwi „wojacy”, którym wejście na salony literackie przychodziło z trudem, ale wspólnymi siłami, połączeni braterską chęcią podzielenia się wspomnieniami o Wielkiej Wojnie Ojczyźnianej dopięli oni jednego - nakreślili obraz wojny według schematu: my dobrzy, oni źli¹.

Ponieważ Astafiew sam był uczestnikiem wojny i jej opisy były wynikiem osobistych doświadczeń, analiza jego wojennej twórczości uwzględniać powinna jego biografię. Taki sposób odczytania książek Astafiewa pozwala lepiej odszyfrować problematykę i zawarte w treści idee przyświecające autorowi. Daje on zarazem możliwość poznania nie tylko indywidualnych cech światopoglądu autora, ale całego szeregu archetypów dotyczących rosyjskiego i w ogóle ogólnoludzkiego podświadomego myślenia. Wanda Supa podkreśla, że „powieściowe zachowanie postaci” syberyjskiego prozaika pozwala „uwzględniać inspiracje behawioryzmu" 2 .

Biorąc pod uwagę powyższe, można stwierdzić, że Astafiew zaproponował inny model wojennej literatury, model oparty na pacyfistycznym ukierunkowaniu, co rozdrażniło radziecką krytykę literacką, niegotową na przyjęcie poglądów pisarza, że każda wojna jest przerażająca, przeciwna

1 Zob.: В.П. А с т а ф ь е в, Собрание сочинений в 15 томах, т. 8, Красноярск 1997, s. 166.

2 W. S u p a, Biblia a wspótczesna proza rosyjska, Białystok 2006, s. 210. 
naturze człowieka. Astafiewowski pacyfizm godził w panujące w radzieckiej polityce doktrynerskie stanowisko, że każdą wojnę można uznać za sprawiedliwą i niesprawiedliwą. Jak podkreśla polski badacz Aleksander Wawrzyńczak, autor Пастуха и пастушки (1967) (Pasterz i pasterka - 1979) chciał pokazać nie bohaterski, a tragiczny obraz wojny ${ }^{3}$, co doprowadziło do tego, że prozaik dosłużył się nawet miana pisarza kontrowersyjnego, wrogo nastawionego do historii swojego narodu. Taką ocenę wystawili mu zwłaszcza radzieccy kombatanci, którzy nie mogli pogodzić się z próbą odbrązowienia Wielkiej Wojny Ojczyźnianej. Osądzali pisarza, piętnowali go, pouczali, żeby w końcu zacząć mu nawet grozić wydłubaniem jedynego ocalałego po odniesionych ranach oka. Pisali do niego listy w imieniu całego narodu, obiecując mu przebicie osinowym kołkiem ${ }^{4}$ Jak zauważa Alicja Wołodźko-Butkiewicz, nie do końca przychylną ocenę wystawili Astafiewowi również "krytycy liberalni i literaci nurtu postmodernistycznego", którzy „uważają go za tradycjonalistę, epigona realizmu krytycznego, uprawiającego niemodne już moralizatorstwo" 5 .

Pierwszymi książkami Astafiewa o tematyce wojennej były: 3вездоnad (1960) (Pora spadających gwiazd i inne opowiadania - 1961), nowela Ясным ли днем (1967) (Czy w jasny dzień - [w:] Antologia opowiadań radzieckich - 1977) oraz nazwana przez autora współczesną pastorałką książka Pasterz i pasterka, które to utwory pozwalają dostrzec mistrzowskie połączenie prozy wiejskiej z prozą wojenną i wypływający z tego połączenia moralno-etyczny światopogląd autora, oceniającego udział Rosji w II wojnie światowej. Należy zaznaczyć, że Astafiew, podkreślający na każdym kroku niepodważalny związek z wiejską kulturą i tradycją chrześcijańskiej religii, wykorzystał to $\mathrm{w}$ interpretacji wojennej historii. W Pasterzu $i$ pasterce wojna pokazana została jako wydarzenie apokaliptyczne, łamiące podstawy wiary, czyli przykazania Boże. Syberyjski prozaik stara się, jak to słusznie zauważył Walentin Kurbatow, przeciwstawić wojnie żywioł życia i płynące z niego takie wartości jak miłość, chęć tworzenia i pracy, konieczność kultywowania wiary, która jest niezwykle ważna, chociażby dla żołnierza postawionego w obliczu śmierci ${ }^{6}$. Podstawą tego utworu była chęć pokazania przez Astafiewa harmonii życia i witalności, w które bezpardonowo wkroczyła

${ }^{3}$ Zob.: A. W a w r z y ń c z a k, Naród i państwo w twórczości pisarzy rosyjskich nurtu „wiejskiego", Kraków 2005, s. 33.

4 Zob.: A. Т а р а с о в, Антисоветское. Как травили Виктора Астафьева, „Новая газета", Москва 5 октября 2009, № 110, [w:] źródło elektroniczne: http://www.solovki. ca/writers_023/023_03.php (22 09.2015).

${ }^{5} \mathrm{~A}$. W o ł o d ź k o - B u t k i e w i c z, Od pieriestrojki do laboratoriów netliteratury. Przemiany we wspótczesnej prozie rosyjskiej, Warszawa 2004, s. 75.

6 Por.: В.Я. К у р б а т о в, Жизнь на миру, В.П. Астафьев, [w:] tegoż, Собрание сочинений в 6-и томах, т. 1, Москва 1991, s. 18. 
wojna. I robi to bardzo obrazowo, jak twierdzi Anna Skotnicka-Maj, która podkreśla celowe epatowanie przez autora okrucieństwem w opisywanych scenach ${ }^{7}$. Wojna w Pasterzu i pasterce to ryk, huk wystrzałów, wstrząsy ziemi wywołane artyleryjską kanonadą, przekleństwa mieszające się z krzykiem rannych i strach przed śmiercią, która zbiera swoje żniwo po obydwu stronach okopów, nie wybierając, kto jest swój, a kto nieprzyjaciel. Obrazy wojny, kreślone wprawną ręką Astafiewa, mają nasuwać na myśl biblijne sceny końca świata. Dla przykładu prozaik odwołuje się do eschatologicznych scen z Apokalipsy św. Jana, gdzie epizod z płonącym niemieckim żołnierzem miał przypominać ognistego anioła śmierci. Takie metaforyczne porównania pozwoliły Alle Bolszakowej nazwać metodę twórczą Astafiewa „symbolicznym realizmem" ${ }^{\prime}$. Według wspomnianego Wawrzyńczaka utwory Astafiewa weszły do kanonu prozy tzw. prawdy okopów, pokazując w sposób realistyczny (aczkolwiek podszyty symboliczno-religijnym znaczeniem, o czym mowa była wyżej - przyp. W. P.-M.) okrutne obrazy wojny, która okalecza psychikę walczących żołnierzy 9 .

Astafiew od samego początku swoich literackich prób związanych z tematyką wojenną wiedział, że najważniejsza dla niego będzie deheroizacja i ściągnięcie romantycznej aureoli z Wielkiej Wojny Ojczyźnianej. W 1951 roku napisał opowiadanie Cywil (Гражданский человек), w którym głównego bohatera Motę Sawincewa przedstawił jako zwykłego człowieka, cywila, który zmuszony został stać się żołnierzem. I to stawanie się żołnierzem pozbawione zostało tak typowej dla literatury socrealizmu pompatyczności i patosu. Sawincew nie urodził się, żeby być dziarskim wojakiem, był zwykłym syberyjskim chłopem, stworzonym do zwykłego życia na wsi. Taki sposób odbrązawiania wszelkich epizodów związanych $\mathrm{z}$ tematyką wojenną stał się dla Astafiewa jego podstawą twórczą.

Na początku lat 90. minionego wieku pisarz sfinalizował swoje główne dzieło o wojnie - powieść Przeklęci i zabici (Прокляты и убиты). W 1992 roku w czasopiśmie „Новый мир” opublikowana została pierwsza część powieści - Czarcia jama (Чертова ямa), a w 1994 roku pojawiła się druga część - Przyczółek (Плащдарм). W książce cały swój przepojony chrześcijańską wiarą światopogląd i płynącą z niego ocenę II wojny światowej Astafiew zaprezentował poprzez kreację szeregu pozytywnych bohaterów, spośród których na szczególną uwagę zasługuje staroobrzędowiec Nikołaj Ryndin, przedstawiciel inteligencji Aszot Wartanian czy dbający o swoich podko-

7 Zob.: A. S k o t n i c k a - M a j, Model prozy „innej” w literaturze rosyjskiej po 1985 roku, Wrocław 2001, s. 78.

8 Zob.: A.Ю. Б о л ь ш а к о в а, Русская деревенская проза ХХ века: код прочтения, Шумен 2002, s. 76.

9 Zob.: A. W a w r z y ń c z a k, op. cit., s. 116. 
mendnych lejtnant Szczuś. W literaturze rosyjskiej jest to zapewne unikatowa książka, w której narratorem stał się nie były oficer polityczny, nie porucznik-dowódca batalionu, lecz zwykły szeregowy żołnierz, który, jak to ujął Paweł Basiński, walczył na pierwszej linii frontu, przeżył, wrócił do domu i nie myślał, że zostanie pisarzem ${ }^{10}$.

Bardzo trafnie ocenił powieść Astafiewa Naum Lejderman, który nie tylko dostrzegł w niej literacko-twórcze podsumowanie wieloletnich rozważań pisarza o takich problemach jak bohaterstwo, deheroizacja, pacyfizm, ale również zauważył, że autor Przeklętych $i$ zabitych nie ograniczył się do opisu wojny z perspektywy batalistycznej, podkreślając przede wszystkim ciężką pracę na rzecz frontu i niewyobrażalnie trudne warunki egzystencji. Dla krytyka niezwykle ważnym okazało się również to, że utwór rosyjskiego prozaika okazał się nie tylko historycznym wspomnieniem, ale także uniwersalną pozycją o czasach teraźniejszych i pouczającą lekcją na przyszłośćc11.

$\mathrm{Z}$ powieści Astafiewa płynie niespotykany w radzieckich książkach o Wielkiej Wojnie Ojczyźnianej humanizm. Wojna jest postrzegana przez pisarza jako wielkie przestępstwo przeciwko ludzkości, które popełniane jest niestety zgodnie z wolą człowieka. Śmierć i niezabliźnione rany można odebrać jako swoisty odwet samej wojny przeciwko samemu człowiekowi, za to, że sprzeniewierzył się on wysokim wartościom, do których został stworzony. W takim pojmowaniu wojennej tragedii Astafiew nie chce wskazywać jednego winnego. Jak słusznie skomentował to Konstantin Azadowski, autor Кражи (1966) (Kradziez - 1988) zrezygnował z pokazywania Niemców jako okrutnych wrogów na tle bezsprzecznie uczciwych i dobrych radzieckich żołnierzy. Odrzucając sformatowany przez propagandę stosunek do niemieckiego żołnierza, prozaik zaczął widzieć w nim nie wroga, ale człowieka12. Taki punkt widzenia został w Rosji odebrany jako próba wręcz wrogiego przeinaczania historii. $\mathrm{Na}$ ataki komunistów i przedstawicieli organizacji nacjonalistycznych Astafiew odpowiedział listem, w którym podkreślił, że to

не Вы, не я и не армия победили фашизм, а народ наш многострадальный. Это в его крови утопили фашизм, забросали врага трупами ${ }^{13}$.

10 Por.: П. Б а с и н с к и й, Контуженная муза. О Викторе Астафьеве, [w:] źródło elektroniczne: http://www.rp-net.ru/book/premia/2009/basinskiy.php?sphrase_id=76 445 (23.09.2015).

11 Zob.: Н. Л е й д е р м а н, Парадоксы коммунального сознания. (О романе В. Астафьева „Прокляты и убиты”"), „Урал” 1994, № 2-3, s. 280.

12 Zob.: К. А з а д о в с к и й, Переписка из двух углов империи, [w:] źródło elektroniczne: http://magazines.russ.ru/voplit/2003/5/azadov.html (23.09.2015).

13 В. А с т а ф ь е в, Письма о войне, правде о ней и иеене Победы, [w:] źródło elektroniczne: http://lazarev35.webtm.ru/?p=786 (23.09.2015): „to nie $\mathrm{Wy}$, nie ja i nie armia 
Opisując koszmar wojny, Astafiew zwrócił uwagę na to, że było to starcie dwóch wojennych maszyn, dwóch ideologii - stalinizmu i hitleryzmu, a biorący $\mathrm{w}$ tym starciu udział zwykli szeregowi żołnierze muszą zostać ukazani tylko jako tragiczne ofiary. Takie niezwykle rzadkie $\mathrm{w}$ rosyjskiej literaturze podejście do tego problemu (chociaż temat ten starali się podejmować Jurij Bondariew, Gieorgij Bakłanow, Bułat Okudżawa czy Wasyl Bykau) pozwala zinterpretować powieść, jak słusznie sądzi Wanda Supa, z pozycji chrześcijańskiej aksjologii. W treść Przeklętych i zabitych wpisana została bezpardonowa krytyka sowieckiej władzy i wszelkiego rodzaju wojen, czemu pisarz przeciwstawił chrześcijańskie ideały, mówiące o szanowaniu bliźniego, o konieczności przebaczania, o pokucie ${ }^{14}$. Tak samo sądzi Wołodźko-Butkiewicz, która podkreśla:

podobnie jak inni rosyjscy pisarze moraliści - Aleksander Sołżenicyn i Władimir Maksimow - Astafiew szuka ratunku w chrześcijaństwie, w Bogu, choć, jak sam powiada, był za młodu „ateistą-bezbożnikiem”15.

Opisy wojny w powieści odarte zostały z aureoli chwały, blichtru pozłoty i dźwięków pompatycznej muzyki. Astafiewowski wojenny pejzaż przesiąknięty został krwią, cierpieniem i strachem przed śmiercią. Cierpiąc z powodu ataku krytyki, pisarz na spotkaniach z czytelnikami mówił: „Я не буду врать о войне. Я был именно на такой войне. На войне было такое, чего вообще быть не может"16. Pisarz doskonale wiedział, prowadząc korespondencję z takimi jak on, byłymi uczestnikami wojennych wydarzeń, że podzielają oni jego punkt widzenia. Wiedział też, że krytyka atakuje go z powodów koniunkturalnych i politycznych, nie mogąc przyjąć przepojonego chrześcijańską myślą osądu o nie tak odległej historii. W Przeklętych i zabitych pojawił się mianowicie wcześniej niespotykany wątek mówiący o sowieckiej Rosji jako o państwie ateistycznym, które wysyłając żołnierzy na front, pozbawiło ich możliwości duchowego ukojenia w modlitwie. Syberyjski prozaik zdawał sobie sprawę z faktu, że wiara w Boga jest niezwykle ważna, gdyż wywodzi się z tradycji i podświadomej psychiki człowieka. Dobrym przykładem tego byli ci, którzy w momentach trwogi szukali wsparcia w modlitwie, chociaż wielu nie wiedziało jak to się robi. Pisarz porównuje radzieckich żołnierzy do żołnierzy carskiej Rosji, którzy mieli prawo otwarcie wierzyć w Boga, mając nadzieję na Jego obronę i błogosła-

pokonały faszyzm, lecz lud, który musiał wiele wycierpieć. To w jego krwi utopiono faszyzm, zarzucając wroga trupami" (tłumaczenie moje - W. P.-M.).

14 W. S u p a, op. cit., s. 208.

${ }^{15}$ A. W oło d ź k o - B u t k i e w i c z, op. cit., s. 81.

${ }^{16}$ Н. Щ е д р и н а, У нее был свой Астафььељ, „День и ночь” 2014, № 2, [w:] źródło elektroniczne: http://magazines.russ.ru/din/2014/2/18sch-pr.html (22.09.2015): „Nie będę kłamać o wojnie. Ja byłem właśnie na takiej wojnie. Na wojnie działy się takie rzeczy, jakie w ogóle dziać się nie powinny" (tłumaczenie moje - W. P.-M.). 
wieństwo. Ważnym aspektem poruszonym w tym kontekście jest również to, że Astafiew mówi o żołnierzach, którzy przed wyruszeniem na front przeszli trudną szkołę życia w koszarach, w „wojskowym czyśćcu” pod Berdskiem, gdzie wszystko, zdaniem Supy, przypominało „obóz koncentracyjny, gdyż ludzie tu również głodują, chorują i umierają"17. Na problem ten zwraca uwagę również Wawrzyńczak, który słusznie podkreśla, że dla takich ludzi państwo, za które mieli iść się bić, niczym się nie różniło od hitlerowskich Niemiec. Bohaterowie powieści rozumieją, że jest to walka pomiędzy dwoma złymi systemami: faszyzmem i komunizmem, i dla zwykłego żołnierza nie będzie zwycięskiego zakończenia - pozostanie mu tylko śmierć albo życie w zwycięskim, ale przeklętym kraju ${ }^{18}$.

$W$ powieści Astafiewa cierpią wszyscy, z tym że ci wierzący mogą znaleźć ukojenie w modlitwie, a Bóg daje im nadzieję na uratowanie. Autor jest przekonany, że dla każdego żołnierza, widzącego ginących masowo tuż obok towarzyszy, tylko wiara w Boga może dać wiarę w jakiś cud. Prawda okopów zaproponowana przez pisarzy socrealistycznych mówiła tylko o oddawaniu życia za Ojczyznę i Stalina. Wśród bohaterów Przeklętych i zabitych czytelnik znajdzie takich, którzy myśleli inaczej. Są to potomkowie rodzin staroobrzędowych (Ryndin), byli oficerowie armii carskiej (Szpator), wrogowie ludu-kułacy (Fiokła) i in. Łączy ich jedno - wiara w Boga, wiara, z którą się nie skrywają, co widoczne jest chociażby w postępowaniu Koli Ryndina. Jest on człowiekiem, który w myśl swoich religijnych przekonań gotowy jest wspierać duchowo innych żołnierzy, dzieląc się także z nimi swoim współczuciem w stosunku do Niemców. Wypływa stąd ostra krytyka wojny, której przeciwstawiona została idea miłości do bliźniego, niepomijająca nawet najbardziej znienawidzonego wroga. Należy podkreślić, że prozaik swojego religijnego światopoglądu nie utożsamiał $\mathrm{z}$ wiarą $\mathrm{w}$ rolę, jaką odgrywała Cerkiew prawosławna. Według niego najważniejszym elementem poszukiwania przez człowieka drogi do poznania Boga powinno być jego sumienie. Brak wsparcia ze strony Kościoła przyczynił się jego zdaniem do nieszczęść, które spotkały jego współrodaków. Przedstawiciele Cerkwi ustąpili miejsca wszelkiej maści politrukom, którzy z przekonaniem wpajali komunistyczną propagandę, mówiącą, że jedynym bogiem jest teraz Stalin. W swojej powieści Astafiew pokazuje, że dla władzy sowieckiej nie tyle ważne było przygotowanie do walki z wrogiem, co "wychowanie" za wszelką cenę własnego narodu. W atmosferze głodu, zimna i strachu codziennie przeprowadzana była ideologiczna nauka, mająca na celu sprawdzenie nie gotowości bojowej, lecz światopoglądowej postawy żołnierzy. Takiej indoktrynacji poddawany jest również Ryndin, ale jest on odporny na zabiegi swoich przełożonych. Wpojony od dziecka staroobrzę-

17 W. S u p a, op. cit., s. 213.

18 Zob.: A. W a w r z y ń c z a k, op. cit., s. 36. 
dowy model życia, oparty na modlitwie, pokorze i przestrzeganiu postów, ukształtował w nim wewnętrzną mądrość i siłę, które nie pozwalają mu zapomnieć o tym, co w życiu jest najważniejsze. Widocznie dlatego w Niemcach widzi on nie tylko faszystów, ale przede wszystkim ludzi, którzy podobnie jak on rzuceni zostali w wir wojny. Astafiew pokazuje czytelnikowi zupełnie odbiegający od tradycyjnej radzieckiej literatury portret Niemca o nazwisku Lemke, w którego charakterze odnajdujemy cechy pozwalające przyrównać go do Ryndina. Obu bohaterów łączy miłosierdzie dla przeciwnika w obliczu śmierci, zbierającej swoje żniwo po każdej stronie barykady, którą jest forsowany od wielu dni Dniepr, nazwany w powieści Wielką Rzeką, mogącą metaforycznie nawiązywać do mitologicznej rzeki Styks. Ważne w warstwie treściowej jest również to, że potworność wojny i związany z nią przenikający wszystko swąd rozkładających się ciał poległych żołnierzy opisane są z punktu widzenia nie tylko Rosjan, ale również Niemców. Zarówno dla jednych, jak i dla drugich wojna stała się obrzydliwym apokaliptycznym wydarzeniem, które nie tylko zaprzecza przykazaniom Bożym, ale również, co bardzo mocno zaznacza autor, może wypaczyć w ludziach obraz Stwórcy. Astafiew jest przekonany, ze wojna przyczynia się do przesuwania $\mathrm{w}$ niepamięć najważniejszych rzeczy naszego istnienia. A czym one są, stara się mówić o tym epigraf do pierwszej części książki, będący fragmentem listu do Galatów św. apostoła Pawła: „A jeśli u was jeden drugiego kąsa i pożera, baczcie, byście się wzajemnie nie zjedli" [Ga 5:15]. Zapomnienie o poszanowaniu drugiego człowieka prowadzi do wojny, której Astafiew nie nazywa inaczej niż bratobójstwem. A to z kolei prowadzi do tego, że ludzie w obliczu wojennego okrucieństwa zaczynają myśleć, że Bóg się od nich odwrócił, ze stał się Bogiem karzącym za grzechy, za bratobójstwo. Rodzą się wręcz heretyckie myśli, czego przykład czytelnik znajdzie w drugiej części powieści:

Боже Милостивый! Зачем Ты дал неразумному существу в руки такую страшную силу? Зачем Ты прежде, чем созреет и окрепнет его разум, сунул ему в руки огонь? Зачем Ты наделил его такой волей, что превыше его смирения? Зачем Ты научил его убивать, но не дал возможности воскресать, чтоб он мог дивиться плодам безумия своего?19

Kolejna próba sforsowania Wielkiej Rzeki, opłacona kolejnymi ofiarami, kończy się sukcesem. Wróg zostaje pokonany, ale finał nie wydaje się optymistyczny. Dla Astafiewa cena, jaką musiano płacić za takie zwycię-

19 В. А с т а ф ь е в, Прокляты и убиты, Москва 2007, s. 780:

Boże Miłościwy! Dlaczego dałeś nierozumnej istocie w ręce taką straszną siłę? Dlaczego Ty, zanim dojrzeje i okrzepnie jej rozum, wsunąłeś jej w ręce ogień? Dlaczego obdarzyłeś ją taką wolą, która jest ponad jej pokorę? Dlaczego nauczyłeś ją zabijać, ale nie dałeś możliwości odradzania się, żeby mogła dziwić się owocom swojej bezmyślności?

(tłumaczenie moje - W. P.-M.). 
stwa na polach II wojny światowej, była zbyt wysoka. Finał Wielkiej Wojny Ojczyźnianej umocnił pozycję Stalina, nie dając nadziei na lepsze jutro dla milionów mieszkańców Kraju Rad i pozostających pod politycznym protektoratem Związku Sowieckiego państw Europy Środkowej. Można zgodzić się z opinią Supy, że „w odsłanianiu o dawnym ZSRR prawd najbardziej niepochlebnych i okrutnych Astafiew posunął się chyba jeszcze dalej niż Sołżenicyn czy inni pisarze antyradzieccy w latach 70. i 80." 20 Syberyjski prozaik był przekonany, że żadna wojna nie rozwiązuje problemów, pozostawiając tylko trudno zabliźniające się rany oraz niepowetowany żal po poległych. Dlatego też powieść Przeklęci i zabici należy odczytać wyłącznie $\mathrm{w}$ kategorii ostrzeżenia przed błędami, mogącymi doprowadzić do kolejnych siłowych rozwiązań. Symptomatyczne $w$ związku z tym mogą być słowa pisarza z jego Dziennika epistolarnego (Эпистолярный дневник 1952-2001):

Я порой думаю, неужели тяжкие времена и страшные беды нас, русский народ, ничему не научили? Неужели желающие нового помрачения российского разума, новой свалки и братоубийства снова зачернят здравый смысл, с таким трудом, через такое горе, такие громадные потери к нам возвращающийся? Новой смуты, еще одной свалки нам не пережить, не хватит на это наших ослабевших, редеющих рядов, поврежденного, если не надорвавшегося, российского здоровья. Не поддавайтесь сатанинским силам, русские люди! Постарайтесь жить по справедливости, быть милосердными друг к другу и нетерпимыми ко злу, разрушающему души...21

Powyższe słowa, mimo iż mogły dotyczyć wojen w Afganistanie i Czeczenii, należy odczytać jako uniwersalne przesłanie Astafiewa do wszystkich ludzi. W obliczu bieżących wydarzeń na świecie, a zwłaszcza na wschodnich rubieżach Ukrainy, astafiewowska, przepojona głębokim humanizmem myśl wydaje się proroczym ostrzeżeniem. Kontynuując wojenną tematykę w takich utworach jak Tak chce się żyć (Так хочется жить - 1995), Przyton

20 W. S u p a, op. cit., s. 216.

21 В. А с т а ф ь е в, Нет мне ответа... Эпистолярный дневник 1952-2001, сост. и пред. Г. Сапронов, Иркутск 2009, [w:] źródło elektroniczne: http://bookz.ru/authors /astaf_ev-viktor/net-mne-_760/1-net-mne-_760.html (23.09.2015):

Czasami myślę: czyżby ciężkie czasy i nieszczęścia niczego nas, rosyjskiego narodu, nie nauczyły? Czyżby ludzie chcący nowego zamroczenia rosyjskiego umysłu, nowej bijatyki i bratobójstwa znów mieli zmącić zdrowy rozsądek, który z takim trudem, przez takie cierpienia, takie ogromne straty do nas powraca? Nowej smuty, jeszcze jednej bijatyki nie jesteśmy w stanie przeżyć, nie wystarczy na to naszych osłabłych, przerzedzonych szeregów, nadszarpniętego, jeśli nie nadwyrężonego, rosyjskiego zdrowia. Nie ulegajcie szatańskim siłom, rosyjscy ludzie! Postarajcie się żyć sprawiedliwie, być miłosiernymi względem siebie, nie dopuszczając do zła rujnującego dusze...

(tłumaczenie moje - W. P.-M.). 
(Обертон - 1996) сzy autobiograficznym Wesotym żotnierzu (Веселый солdam - 1998), pisarz miał nadzieję, że lektura jego książek będzie pouczającą lekcją dla młodych pokoleń, które, być może, nie popełnią błędów swoich dziadków i ojców.

\section{Bibliografia}

А $з$ а д о в с к и й К., Переписка из двух углов империи, [w:] źródło elektroniczne: http://magazines.russ.ru/voplit/2003/5/azadov.html (23.09.2015).

А с т а ф ь е в В., Нет мне ответа... Эпистолярный дневник 1952-2001, сост. и пред. Г. Сапронов, Иркутск 2009, [w:] źródło elektroniczne: http://bookz.ru/authors/ astaf_ev-viktor/net-mne-_760/1-net-mne-_760.html (23.09.2015).

А с т а ф ь е в В.П., Письма о войне, правде о ней и иене Победы, [w:] źródło elektroniczne: http://lazarev35.webtm.ru/?p=786 (23.09.2015).

А с т а фь е в В., Прокляты и убиты, Москва 2007.

А с т а ф ь е в В.П., Собрание сочинений 615 томах, т. 8, Красноярск 1997.

Б а с и н с к и й П., Контуженная муза. О Викторе Астафьеве, [w:] źródło elektroniczne: http://www.rp-net.ru/book/premia/2009/basinskiy.php?sphrase_id=76445 (23.009.2015).

Б о л ь ш а к о в а А.Ю., Русская деревенская проза ХХ века: код прочтения, Шумен 2002.

К у р б а т о в В.Я., Жизнь на миру, В. П. Астафьев, [w:] tegoż, Собрание сочинений в 6-и т., т. 8, Москва 1991.

Л е й д е р м а н Н., Парадоксы коммунального сознания. (О романе В. Астафььева „Прокляты и убиты"), "Урал" 1994, № 2-3.

Щ е д р и н а Н., У нее был свой Астафьев, „День и ночь”, №2, 2014 [w:] źródło elektroniczne: http://magazines.russ.ru/din/2014/2/18sch-pr.html (22.09.2015).

Т а р а с о в А., Антисоветское. Как травили Виктора Астафьева, „Новая газета", Москва, 5 октября 2009, № 110, [w:] źródło elektroniczne: http://www.solovki.ca/ writers_023/023_03.php (22.09.2015).

S u p a W., Biblia a wspótczesna proza rosyjska, Białystok 2006.

S k o t n i c k a - M a j A., Model prozy „innej" w literaturze rosyjskiej po 1985 roku, Wrocław 2001.

W a w r z y ń c z a k A., Naród i państwo w twórczości pisarzy rosyjskich nurtu "wiejskiego", Kraków 2005.

W o ł o d ź k o - B u t k i e w i c z A., Od pieriestrojki do laboratoriów netliteratury. Przemiany we wspótczesnej prozie rosyjskiej, Warszawa 2004. 